\title{
Virus Transfer at the Skin-Liquid Interface
}

\author{
A. K. Pitol, ${ }^{\dagger, \ddagger}$ Heather N. Bischel, ${ }^{\ddagger}, \S$ Tamar Kohn, ${ }^{\ddagger}$ and Timothy R. Julian ${ }^{*}, \|, \dagger, \perp$ (i) \\ ${ }^{\dagger}$ Eawag, Swiss Federal Institute of Aquatic Science and Technology, 8600 Dübendorf, Switzerland \\ ${ }^{\ddagger}$ Laboratory of Environmental Chemistry, School of Architecture, Civil, and Environmental Engineering (ENAC), École \\ Polytechnique Fédérale de Lausanne (EPFL), CH 1015 Lausanne, Switzerland \\ ${ }^{\S}$ Department of Civil \& Environmental Engineering, University of California, Davis, California 95616, United States \\ "Department of Epidemiology and Public Health, Swiss Tropical and Public Health Institute, Basel, Switzerland \\ ${ }^{\perp}$ University of Basel, Basel, Switzerland
}

\section{Supporting Information}

ABSTRACT: Understanding virus transfer between liquid and skin is necessary to estimate transmission during waterrelated activities. Here, we modeled virus transfer from liquidto-skin and skin-to-liquid. We performed human subject studies using three bacteriophages as pathogenic virus surrogates: nonenveloped MS2 and $\mathrm{Q} \beta$ and enveloped $\Phi 6$. Our study shows that transfer from liquid-to-skin is describable by a single model based on (1) virus concentration and (2) volume of liquid remaining on skin. Contact times (0.1-30 $\mathrm{min})$, and virus species had little-to-no influence on virus transfer. Likewise, liquid conditions ( $\mathrm{pH} 6-9$, ionic strength $10-550 \mathrm{mM}$ ) had no influence on transfer as shown for MS2. The model accounts for both, virus adsorbed onto the skin, and virus in the liquid retained on skin. In comparison, virus transfer from skin-to-liquid was influenced by the wetness of the skin and by liquid type (water, saliva). $90 \pm 19 \%$ of the virus inoculated on the skin are transferred to the water when the skin remains wet compared to $30 \pm 17 \%$ when the skin is dry. The transfer from skin-to-liquid was $41 \%$ higher when the recipient liquid was water as compared with saliva. This study quantifies virus transfer between liquid and skin and guides risk assessments of water-related activities.

\section{INTRODUCTION}

Enteric viruses are one of the leading causes of diarrhea ${ }^{1,2}$ and are responsible for a significant portion of drinking and recreational water outbreaks. ${ }^{3-5}$ Waterborne enteric viruses are mainly transmitted via the fecal-oral route, ${ }^{6}$ including both direct ingestion of contaminated water (inclusive of both accidental and intentional ingestion) and indirect transfer (water-to-hand and hand-to-mouth). To date, risk assessments of waterborne pathogens have largely focused only on direct ingestion. $^{7-9}$ The estimated ingested dose for direct ingestion is calculated based on assumptions of the volume of liquid ingested and concentration of pathogens in the liquid. ${ }^{10}$ Example scenarios include risk assessments for drinking water, ${ }^{11,12}$ swimming, ${ }^{7,13}$ fishing, and canoeing. ${ }^{14}$ In many scenarios neglecting contributions from indirect transmission of pathogens likely underestimates risks, especially where indirect ingestion is more likely than direct ingestion.

In studies that consider the indirect transfer of microorganisms due to water contacts, indirect transfer is estimated based on either estimating volume of the liquid transferred or by performing pathogen transfer experiments. ${ }^{15-17}$ Specifically, De Man et al. estimated total pathogen transfer based on the thickness of the water film that remained on the skin after hand contacts with water, along with information on the pathogen concentration in the water. ${ }^{15}$ In contrast, O'Toole et al. determined experimentally the percentage of bacteria and virus transferred to the hand after contact with contaminated liquid using one specific volume and one specific concentration of pathogens in the water. These studies assume that system properties (such as characteristics of the virus, liquid, and skin) do not influence transfer. However, from the more extensive literature on virus transfer from objects to hands, these factors are known to influence transfer. ${ }^{18-23}$

Understanding virus transfer between liquid and skin is necessary to estimate indirect transmission during water-related activities. Although there is little data available on transfer between liquids and skin, parallels may be observed in the literature of virus transfer between liquids and surfaces, and between surfaces and skin. Viruses are readily transferred from liquid to a variety of surfaces including food, ${ }^{24,25}$ soils, $^{26,27}$ minerals, ${ }^{26}$ sand, $^{28}$ silica, ${ }^{24-31}$ and organic matter. ${ }^{24-31}$ The

Received: September 23, 2017

Revised: November 15, 2017

Accepted: November 21, 2017

Published: November 21, 2017 
a)

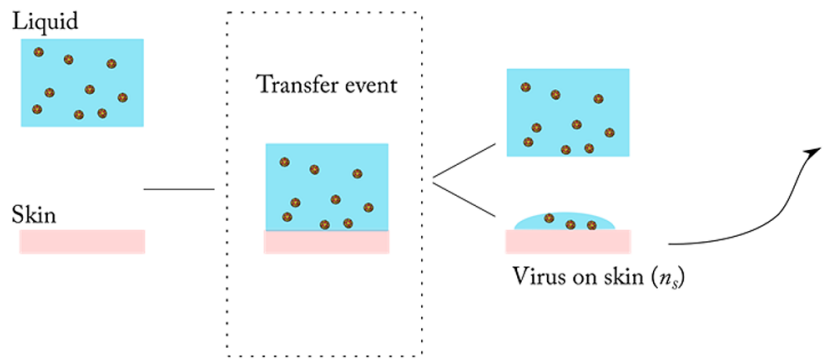

b)

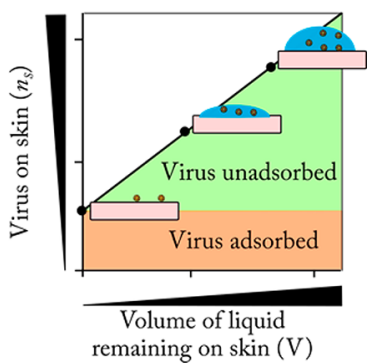

Figure 1. Conceptual model of liquid-to-skin transfer. (a) After skin-liquid contact (transfer event), viruses in the liquid are transferred to the skin $\left(n_{s}\right)$, including adsorbed and unadsorbed fractions. (b) The total number of viruses transferred to the skin, $n_{s}$, is equal to the number of viruses adsorbed onto the skin during the contact event plus the unadsorbed viruses in a volume of liquid remaining on the skin $(V)$.

forces driving virus adsorption to surfaces have been described as a complex combination of electrostatic, hydrophobic and van der Waals interactions. ${ }^{30,32,33}$ Electrostatic forces are modulated by virus and surface characteristics and these characteristics, in a liquid environment, are influenced by liquid properties such as $\mathrm{pH}$ and ionic strength. ${ }^{32,34}$ This is consistent with evidence suggesting that virus adsorption to surfaces is influenced by virus, ${ }^{24,29,30-32}$ liquid, ${ }^{26,28-32,35}$ and surface characteristics,. ${ }^{29-31}$

Transfer of viruses from surfaces-to-skin has been extensively explored, identifying multiple factors that significantly influence it. These factors include: virus species, ${ }^{18,19}$ skin characteristics, ${ }^{19,22}$ fomite characteristics (e.g., material porosity), ${ }^{20,21,23}$ direction of transfer (i.e., finger-to-surface, surface-to-finger), ${ }^{18,19,22}$ humidity, ${ }^{21}$ inoculum drying time, ${ }^{36,37}$ pressure, ${ }^{37}$ and friction. ${ }^{37}$ In contrast, there is virtually no data for skin-toliquid transfer. Rusin et al. (2002) estimated that $34 \%$ of the bacteriophages present in the skin are transferred to the moist environment of lips. ${ }^{20}$ Nevertheless, no measure of variation was provided in their study, and the saliva-rich environment of the lips will probably not reflect other liquid environments.

The objectives of this work were to quantify virus transfer from liquid-to-skin and skin-to-liquid, identify factors (virus species, liquid characteristics, direction of the transfer, concentration and contact time) that influence virus transfer, and increase the accuracy of risk assessments of human interaction with virus-contaminated liquids. The study provides insight into the dynamics of virus transfer at the skin-liquid interface relevant to the environmental spread of viruses.

\section{CONCEPTUAL MODELS}

Virus transfer at the liquid-skin interface is a bidirectional phenomenon: viruses are transferred both from liquid-to-skin and from skin-to-liquid. After sufficient contact time between liquid and skin, the system is expected to achieve equilibrium. However, real-world scenarios of skin and liquid contact require different conceptual models to be useful as data inputs in diverse risk assessment frameworks and modeling. Therefore, in the present work, we modeled the transfer from liquid-to-skin differently than the transfer from skin-to-liquid and designed experimental protocols appropriately for each model. In liquidto-skin transfer, skin is assumed to be in contact with a sufficiently large volume that can be considered infinite relative to the surface area of the skin in contact (i.e., swimming in a lake). Virus transfer will not depend on the absolute number of viruses in the liquid but rather on the concentration of virus in the liquid; the contact time; the surface area of the skin in contact with the liquid; and the physicochemical properties of the skin, liquid, and virus. In contrast, in skin-to-liquid transfer, the skin surface area is finite (relative to the liquid), so the total amount of virus per skin surface area can be estimated. Therefore, skin-to-liquid transfer can be modeled as the percentage of viruses transferred to the liquid after contact, relative to the initial number of viruses on the skin. The number of viruses on the skin is defined as the concentration of viruses on the skin (viruses/area) times the contact area between the liquid and the skin.

Liquid-to-Skin Model. Here, we assume that viruses adsorb to the skin surface during liquid-to-skin contact. The magnitude of adsorption depends on the properties of the system (skin, virus, and liquid characteristics). We refer to this as the "adsorbed" virus. Additionally, contaminated liquid will be retained on the skin (i.e., film thickness), due to incomplete removal of the liquid. We refer to this as the "unadsorbed" virus. We assume the number of unadsorbed viruses is a function of the volume of liquid remaining on the skin and the concentration of viruses in the liquid (Figure 1, eq 1).

Experimentally, adsorbed viruses must be measured after complete removal of the contaminated liquid. The conceptual model of liquid-to-skin transfer is described as

$$
\begin{aligned}
& n_{\mathrm{s}}=n_{\mathrm{ads}}+n_{\text {unads }} \\
& n_{\text {unads }}=C V
\end{aligned}
$$

where $n_{\mathrm{S}}$ is the total number of viruses per unit area on the skin (Plaque-forming units $\left.(\mathrm{PFU}) / \mathrm{cm}^{2}\right), n_{\text {ads }}$ is the number of adsorbed viruses per unit area $\left(\mathrm{PFU} / \mathrm{cm}^{2}\right)$ and $n_{\text {unads }}$ is the number of unadsorbed viruses per unit area $\left(\mathrm{PFU} / \mathrm{cm}^{2}\right)$ (eq 1$)$. $n_{\text {unads }}$ can be estimated using concentration of viruses in the liquid, $C(\mathrm{PFU} / \mathrm{mL})$, and the volume of liquid retained per unit area on the skin, $V\left(\mathrm{ml} / \mathrm{cm}^{2}\right)$ (eq 2). Inactivation is not accounted for in the model because no significant inactivation of the viruses in the liquid is expected to happen on the time scale of the transfer event, $\leq 30 \mathrm{~min},{ }^{38,39}$ as supported by the relatively low inactivation rates of bacteriophages $\Phi 6$ (enveloped) and MS2 (nonenveloped) in liquid at $25{ }^{\circ} \mathrm{C}$ (approximately 0.044 and $\left.0.020 \mathrm{~h}^{-1}\right) .{ }^{39}$ Additionally, this model assumes no concentration gradient in the bulk liquid results from adsorption of viruses onto the skin. Because the concentration of viruses in the liquid is orders of magnitude higher than the number of viruses adsorbed onto the skin, it is unlikely that adsorption causes a meaningful gradient.

Skin-to-Liquid Model. In scenarios where contaminated skin is in contact with liquid, we hypothesize that a fraction of the viruses on the skin will be transferred to the liquid (Figure 


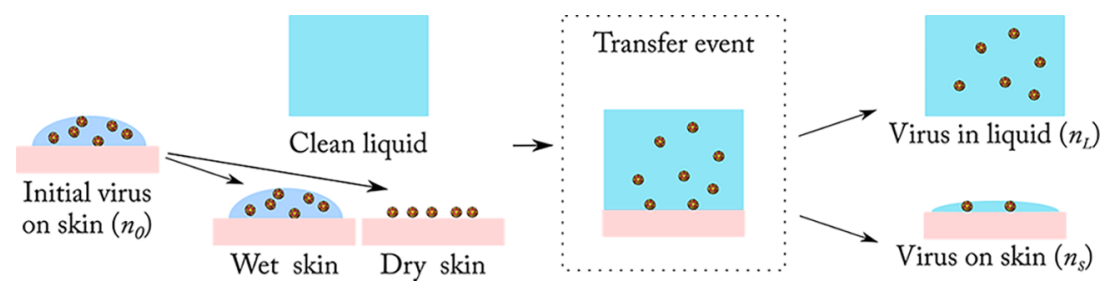

Figure 2. Conceptual model of skin-to-liquid transfer. A known number of viruses initially on the skin $\left(n_{0}\right)$, due for example to contact of the skin with a contaminated liquid, are subsequently transferred from wet contaminated skin or dried contaminated skin to a new clean liquid. After this secondary skin-to-liquid contact (transfer event), a portion of the viruses on the skin will be transferred to the liquid $\left(n_{\mathrm{L}}\right)$ and a portion of the viruses will remain on the skin $\left(n_{\mathrm{s}}\right)$.

Table 1. Cohort Studies' Description. The Direction of the Transfer, Experimental Design, Treatment Tested, Bacteriophage Used, Number Volunteers, Sessions, And Transfer Events $(N)$ for Every One of the Three Human Subject Studies ${ }^{a}$

\begin{tabular}{|c|c|c|c|c|c|c|c|}
\hline study & direction & set-up & treatment & phages & volunteers & sessions $^{a}$ & $N$ \\
\hline${ }^{b} \mathrm{~A}$ & liquid $\rightarrow$ skin & finger immersion & $\begin{array}{l}\text { concentration }\left[10^{6}, 10^{7}, 10^{8} \mathrm{PFU} / \mathrm{ml}\right] \\
\text { time }[0.1,1,10,10 \mathrm{~min}]\end{array}$ & $\begin{array}{l}\text { MS2 } \\
\mathrm{Q} \beta \\
\Phi 6\end{array}$ & 7 & 27 & 210 \\
\hline B & liquid $\rightarrow$ skin & finger immersion & $\begin{array}{l}\mathrm{pH}[6,7.5,9] \\
\text { ionic strength }[10,550 \mathrm{mM}]\end{array}$ & MS2 & 7 & 7 & 94 \\
\hline $\mathrm{C}$ & skin $\rightarrow$ liquid & droplet transfer & $\begin{array}{l}\text { liquid [saliva, water] } \\
\text { drying [wet, dry] }\end{array}$ & MS2 & 7 & 7 & 56 \\
\hline
\end{tabular}

${ }^{a}$ Session $=$ number of times any of the volunteers visited the laboratory to perform a transfer experiment. PFU $=$ plaque-forming units. $N=$ individual transfer event $=$ sample size. ${ }^{b}$ In study A, two volunteers were assigned two different bacteriophages and 5 volunteers where assigned only one bacteriophage. For each bacteriophage assigned, the volunteers visited the laboratory three times (three sessions).

2). The number of viruses transferred to the liquid can be modeled as a skin-to-liquid transfer efficiency $\left(\mathrm{TE}_{\mathrm{S}-\mathrm{L}}\right)$. In the present study, we calculate transfer efficiency using two distinct but related estimates: theoretical $\mathrm{TE}_{\mathrm{S}-\mathrm{L}}$ and recoverable $\mathrm{TE}_{\mathrm{S}-\mathrm{L}}$.

The theoretical $\mathrm{TE}_{S-\mathrm{L}}$ (eq 3 ) is defined as the number of viruses recovered in the liquid $\left(n_{L}\right)$ relative to the initial number of viruses on the skin $\left(n_{0}\right)$. This is parallel to equations reported by O'Toole et al., ${ }^{40}$ and can be used in cases where a known amount of contaminated liquid on the hand is followed by a transfer event. This fraction does not take into account irreversible adsorption of virus onto the skin or virus inactivation.

$$
\text { theoretical } \mathrm{TE}_{\mathbf{S}-\mathbf{L}}[\%]=\frac{n_{\mathrm{L}}[\mathrm{PFU}]}{n_{0}[\mathrm{PFU}]} \times 100
$$

In contrast, the recoverable $\mathrm{TE}_{\mathrm{S}-\mathrm{L}}$ is defined as the number of viruses recovered in the liquid $\left(n_{\mathrm{L}}\right)$, relative to the viruses recovered from the sum of liquid $\left(n_{\mathrm{L}}\right)$ and skin $\left(n_{\mathrm{S}}\right)$ (eq 4$)$. Virus inactivation is implicit in this equation. This is similar to fomite-mediated transfer equations reported elsewhere, ${ }^{19-21}$ where the transfer efficiency is calculated using only recoverable virus.

$$
\text { recoverable } \mathrm{TE}_{\mathrm{S}-\mathrm{L}}[\%]=\frac{n_{\mathrm{L}}[\mathrm{PFU}]}{n_{\mathrm{L}}[\mathrm{PFU}]+n_{\mathrm{S}}[\mathrm{PFU}]} \times 100
$$

In addition to the transfer efficiencies, we calculated the total recovery, which is the total amount of viruses that could be recovered after the transfer event, defined as the sum of viruses recovered in the liquid and skin $\left(n_{\mathrm{L}}+n_{\mathrm{S}}\right)$, relative to the initial number of viruses on the skin $\left(n_{0}\right)$. A $100 \%$ total recovery would imply no loss of viruses during the experiment due to factors such as inactivation or irreversible adsorption.

$$
\text { total recovery }[\%]=\frac{n_{\mathrm{L}}[\mathrm{PFU}]+n_{\mathrm{S}}[\mathrm{PFU}]}{n_{0}[\mathrm{PFU}]} \times 100
$$

\section{EXPERIMENTAL SECTION}

Bacteriophage Production, Purification, and Enumeration. We selected bacteriophages MS2, $\mathrm{Q} \beta$, and $\Phi 6$ for this study. Both MS2 and $\mathrm{Q} \beta$ are similar to enteric viruses of human health concern. ${ }^{41}$ Their isoelectric points (IEPs) are 3.9 and 4.9, respectively, ${ }^{30}$ which are close to the IEPs of Human Adenovirus (4.5). ${ }^{34}$ Similar to Human Enterovirus, Coxsackie virus, and Poliovirus, both MS2 and $\mathrm{Q} \beta$ have (+) singlestranded RNA genomes and are nonenveloped. Despite their similitudes with each other, MS2 and $\mathrm{Q} \beta$ have very different adsorption behavior at the solid-water interface due to differences in their surface charge and polarity. ${ }^{30}$ We selected $\Phi 6$ as a surrogate for enveloped viruses. Bacteriophage $\Phi 6$ has a lipid envelope, double-stranded RNA genome, and has been used in the past as a surrogate for a variety of enveloped viruses, $^{39,42-45}$ including Ebola. ${ }^{42}$

Bacteriophage MS2 (DSMZ 13767), QB (DSMZ 13768), and $\Phi 6$ (DSMZ 21518), together with their respective hosts, $E$. coli (DSMZ 5695) for MS2 and $\mathrm{Q} \beta$ and P. syringae (DSMZ 21482) for $\Phi 6$, were purchased from the DSMZ German Collection of Microorganisms and Cell Cultures (Braunschweig, Germany). To grow and purify the bacteriophages we used a protocol adapted from Armanious et al. ${ }^{30}$ Briefly; $1 \mathrm{~L}$ of Tryptone Soya Broth (AppliChem) containing log-phase bacteria was inoculated with $100 \mu \mathrm{L}$ of a $10^{10}$ Plaque Forming Units $(\mathrm{PFU}) / \mathrm{mL}$ stock of bacteriophage and incubated overnight. The sample was clarified by centrifugation for 15 min at $4000 \mathrm{~g}$. The supernatant was concentrated using an 
Amicon Ultra centrifugal filter device (100 kDa; Merk Millipore).

The double agar layer procedure was used to enumerate infective bacteriophages. ${ }^{46}$ Shortly, bacteriophage (MS2, $\mathrm{Q} \beta$ or Ф6) was combined with host bacteria (E. coli or P. syringae) in soft agar ( $0.7 \%$ Agar) and poured into a plate containing hard agar ( $1.5 \%$ agar). A positive control consisting of $E$. coli host with a known concentration of bacteriophage and a negative control consisting of $E$. coli host with no bacteriophage were plated each time.

Study Design. We performed three cohort studies (A, B, and $C$ ), each with seven volunteers (male and female, 18-35 years old). Two (A and B) studied virus transfer from liquid-toskin. The third (C) studied the transfer of virus from skin-toliquid (Table 1). Written consent was obtained from all volunteers, and the experimental design was approved by the Research Ethics Committee of ETH Zurich. Volunteers were not asked to wash their hands or apply any antibacterial agent (such as alcohol-based disinfectant) prior to the experiment to mimic skin conditions likely encountered under natural conditions. Preparing hands by cleaning has previously been shown to significantly lower transfer efficiency of viruses between hands and surfaces. ${ }^{19,22}$ The hands of the volunteers were inspected before the experiment to ensure no skin damage. In studies A and B, the volunteers were asked to dip their fingers into a liquid containing bacteriophages ("finger immersion"). In study $C$, the volunteers' hands were contaminated with bacteriophages and, subsequently, the bacteriophages were recovered from the skin using different liquids ("droplet transfer").

Virus Transfer from Liquid-to-Skin. Virus transfer from liquid-to-skin was investigated as a function of virus concentration, virus species, liquid characteristics, and the contact time between the subject's hand and the liquid solution. Cohort study A (seven subjects) was performed to investigate the influence of contact time and concentration on virus adsorption to the skin. Each one of the volunteers was assigned to one or two different bacteriophages (MS2, $\mathrm{Q} \beta$ or $\Phi 6$ ). The volunteers were asked to come to the laboratory three times (three sessions), one for each concentration tested $\left(10^{6}, 10^{7}\right.$, $10^{8} \mathrm{PFU} / \mathrm{mL}$ ), if one bacteriophage was assigned and 6 times if two bacteriophages were assigned.

A description of the experimental method with images can be found in the Supporting Information (SI) (Figure S1). Briefly, a circular area (diameter $=5 \mathrm{~mm}$ ) was delimited in each finger of the volunteer using the rim of a $20 \mu \mathrm{L}$ pipet tip dipped in Vaseline (Vifor Pharma). We used Vaseline to delimit the circumference of the area sampled because of its hydrophobic properties and because virus adsorption to Vaseline is at least 1 order of magnitude lower than virus adsorption to the skin, as shown using MS2 (Supporting Information, S1.1). Subsequently, the volunteer was asked to dip $\sim 5 \mathrm{~cm}$ of each finger into a flask containing a phosphate buffered saline solution (5 mM PO4-3 (Sigma-Aldrich) - $10 \mathrm{mM} \mathrm{NaCl}$ (Sigma-Aldrich) $\mathrm{pH} 7.5 \pm 0.1)$ with bacteriophage (MS2, QB, or $\Phi 6)$ at different concentrations $\left(\sim 10^{6}-10^{8} \mathrm{PFU} / \mathrm{mL}\right)$. Each finger of the hand was immersed in the solution for a set period of time (between 5 and $1800 \mathrm{~s}$ ) such that each hand could test five experimental conditions at a time. For each volunteer, one hand was the replicate of the other. Subsequently, the area inside the Vaseline was sampled. Sampling the area consisted of two consecutive rinsing steps. The first rinsing was performed pipetting up and down one time using the same phosphate buffered saline solution, to remove the "unadsorbed bacteriophages", and the second rinsing was performed pipetting up and down five times using a beef extract solution (3\% beef extract (Sigma-Aldrich) - 0.1 M glycine (Fluka)- $\mathrm{pH} 8$ ), to remove the "adsorbed bacteriophages". Beef extract is a high ionic strength, high protein content solution used to desorb virus from surfaces. ${ }^{32,47}$ Every experiment had two negative controls, which consisted in sampling the area inside the Vaseline for the two fingers that were not used in the experiment. At the end of the experiment, subjects washed their hands with soap and disinfected with $70 \%$ ethanol.

Cohort study B was performed to investigate the effect of solution characteristics on virus transfer. We used the method previously described with some modifications: After application of Vaseline, the subjects were asked to dip the fingers into a flask containing different buffers with MS2 at a concentration of $\sim 10^{7} \mathrm{PFU} / \mathrm{mL}$. To test the influence of liquid $\mathrm{pH}$ and ionic strength, six different buffers were used: $5 \mathrm{mM}$ PO4-3-10 $\mathrm{mM} \mathrm{NaCl}-\mathrm{pH} 6 \pm 0.1,5 \mathrm{mM}$ PO4-3-550 mM NaCl - $\mathrm{pH} 6$ $\pm 0.03,5 \mathrm{mM}$ PO4-3-10 mM NaCl $-\mathrm{pH} 7.5 \pm 0.07,5 \mathrm{mM}$ PO4-3-550 mM NaCl - pH 7.5 $\pm 0.04,5 \mathrm{mM}$ PO4-3-10 $\mathrm{mM} \mathrm{NaCl}-\mathrm{pH} 9 \pm 0.03,5 \mathrm{mM}$ PO4-3-550 mM NaCl $-\mathrm{pH}$ $9.1 \pm 0.37$. Sixty seconds after the immersion of the fingers, the area inside the Vaseline was sampled as previously described.

Quantifying Virus Transfer from Skin-to-Liquid. Two scenarios of virus transfer from skin-to-liquid were evaluated: "Wet-Transfer" and "Dry-Transfer" (SI Figure S2). In both cases, a circular area (diameter $=5 \mathrm{~mm}$ ) was delimited on the skin of the volunteer using Vaseline. Twenty microliters of saline buffer ( $5 \mathrm{mM}$ PO4-3-10 $\mathrm{mM} \mathrm{NaCl}-\mathrm{pH} 7.5 \pm 0.1$ ) containing MS2 at a concentration of $\sim 10^{7} \mathrm{PFU} / \mathrm{ml}$ were pipetted onto the area inside the Vaseline (inoculum). The transfer occurred five seconds after inoculating the skin-when the droplet was still wet-or after the inoculum was visibly dried (between 15 and $30 \mathrm{~min}$ after inoculation). Transfer consisted of adding $20 \mu \mathrm{L}$ of Milli-Q water or $20 \mu \mathrm{L}$ of the volunteer's saliva in the area inside the Vaseline. Immediately after addition, the full volume of the liquid was recovered. Subsequently, the skin was sampled by pipetting up and down five times using beef extract solution.

Statistical Analyses. The data were analyzed using the $\mathrm{R}$ statistical software (The R Foundation for Statistical Computing Platform, version 3.2.2). The significance of the difference in virus transfer between the different conditions was assessed using n-way ANOVA with Tukey's post hoc comparisons for time and liquid conditions ( $\mathrm{pH}$ and ionic strength) as well as for skin-to-liquid transfer. Linear regression models were used to assess the influence of bacteriophage concentration and virus species in virus transfer from liquid-to-skin. Statistical significance was assessed using a significance level of 0.05. All the analyses were conducted using the $\log _{10}$ transformed data.

\section{RESULTS}

Virus Transfer from Liquid-to-Skin. A total of 210 transfer events in 27 sessions with seven volunteers were carried out. None of the negative controls showed bacteriophage contamination, implying the skin of the volunteers was free of the bacteriophages tested. Total virus transfer (adsorbed + unadsorbed) ranged from $3 \times 10^{3}$ to $4 \times$ $10^{6} \mathrm{PFU} / \mathrm{cm}^{2}$ when concentrations of virus in the liquid varied between $\sim 10^{6}$ and $\sim 10^{8} \mathrm{PFU} / \mathrm{cm}^{3}$. The strongest predictor of virus transfer from liquid-to-skin was the concentration of bacteriophage in the liquid. Viral transfer scaled linearly with 

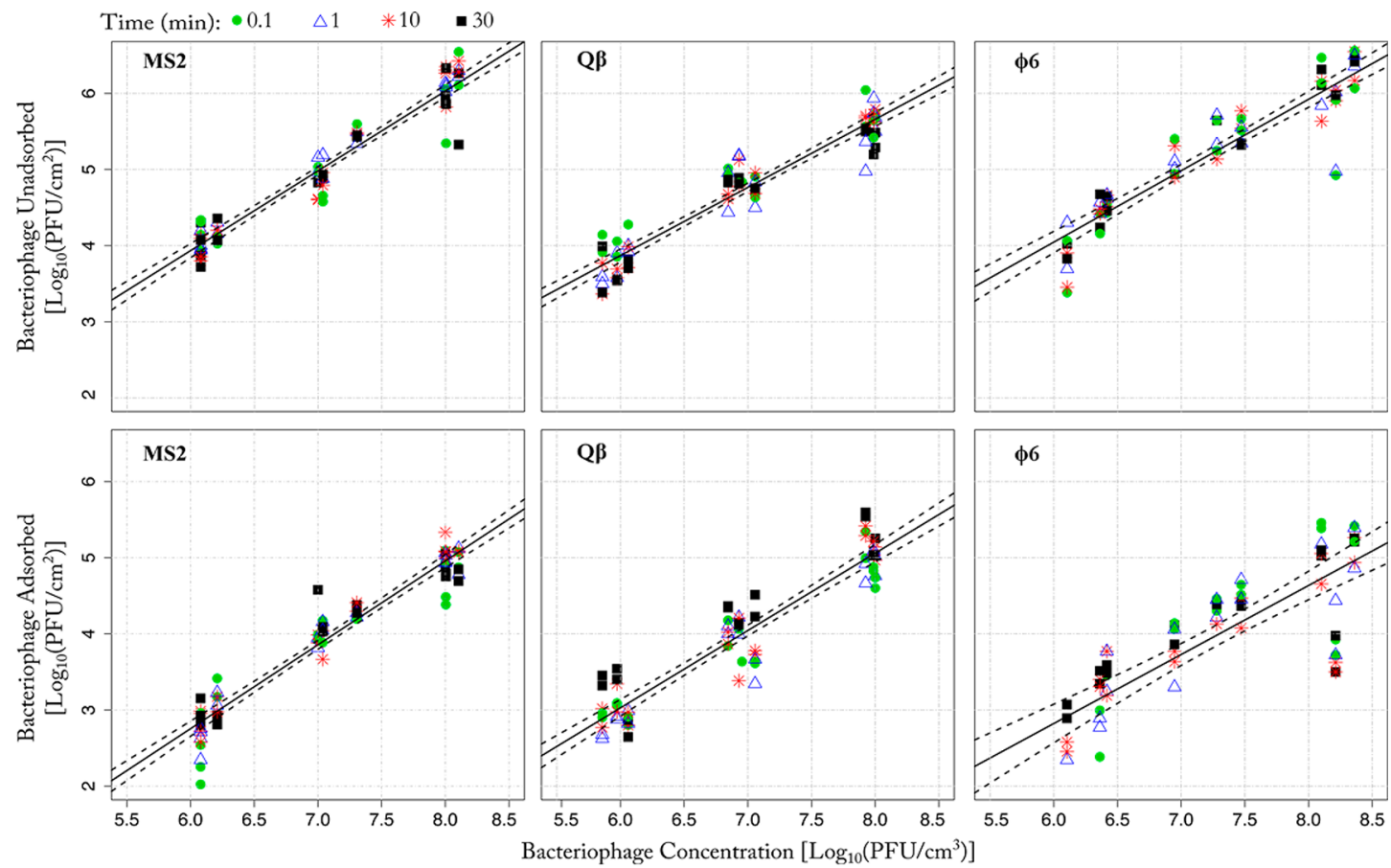

Figure 3. Linear regression of the $\log _{10}$ transformed bacteriophage (MS2, $\Phi 6, \mathrm{Q} \beta$ ) transferred to the skin (adsorbed and unadsorbed) as a function of the $\log _{10}$ transformed concentration of bacteriophage in the liquid. Four different contact times: 0.01 (green circle), 1 (blue triangle), 10 (red asterisk) and $30 \mathrm{~min}$ (black square) were evaluated. The 95\% CIs for each regression line are shown in dotted lines. All figures share the same axes.
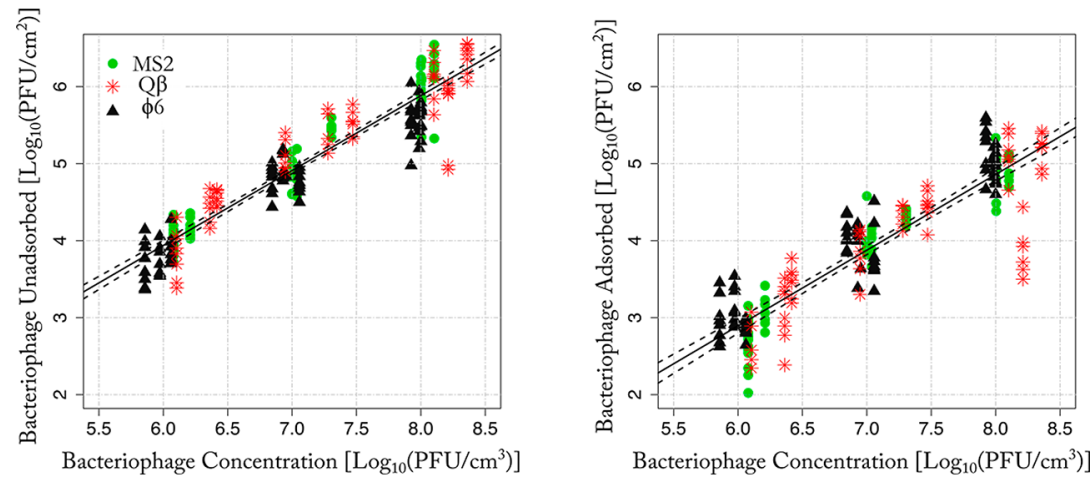

Figure 4. Linear regression for all bacteriophages (MS2, $\mathrm{Q} \beta$, and $\Phi 6)$ transferred to the skin (adsorbed and unadsorbed) as a function their concentration in the liquid. The linear regression's $95 \%$ CIs are shown in dotted lines.

concentration (Figure 3). Using linear regression, concentration alone explained $88 \%$ of the variance in the unadsorbed (Linear Regression, $F(1,209)=1635, p<0.001)$ and $79 \%$ of the variance in the adsorbed $(F(1,209)=771.5, p<0.001)$ fraction of bacteriophages on the skin after a contact event.

When accounting for concentration, contact time between the liquid and the skin influenced the transfer of bacteriophage $\mathrm{Q} \beta$, but not MS2 nor $\Phi 6$. In the case of $\mathrm{Q} \beta$, there was a significant main effect of the time that the finger spent under the water on the unadsorbed fraction of virus transferred to the skin (two-way ANOVA, $F(3,60)=3.28, p=0.03, \eta p^{2}=0.14$ ) (SI Figure S3 and S4). Tukey post hoc test revealed that the amount of $\mathrm{Q} \beta$ transferred when contact time was $30 \mathrm{~min}$ was statistically lower than $5 \mathrm{~s}(p=0.015)$. We found a significant effect of contact time on the amount of virus adsorbed onto the skin $\left(F(3,60)=9.52, p>0.001, \eta p^{2}=0.32\right)$. Tukey post hoc test revealed that the adsorption of $\mathrm{Q} \beta$ when the contact time was 30 min was significantly higher than the adsorption at $5 \mathrm{~s}, 1$ and $10 \mathrm{~min}(p>0.001, p>0.001, p=0.01)$. Nevertheless, the total transfer of $\mathrm{QB}$-the adsorbed plus the unadsorbed fractionwas not influenced by contact time $(F(3,60)=1.31, p=0.28)$. In the case of bacteriophages MS2 and $\Phi 6$, we found no statistically significant difference in the unadsorbed fraction $(F$ $(3,59)=0.46, p=0.71),(F(3,56)=0.25, p=0.86)$ or in the adsorbed fraction $(F(3,59)=1.18, p=0.32),(F(3,56)=$ 1.18, $p=0.32$ ).

Bacteriophage species had a statistically significant influence on both the unadsorbed and the adsorbed fraction of bacteriophage transferred to the skin, but the effect size was small. Specifically, the contribution to the total variance explained by bacteriophage species was less than 2\% (Figure 4). Additionally, liquid characteristics as described by liquid $\mathrm{pH}$ [6-9] and Ionic Strength [10-550 mM] did not significantly influence the unadsorbed $(p=0.81, p=0.70)$ or the adsorbed $(p=0.60, p=0.44)$ number of viruses transferred from liquid to the skin (Figure S5).

Modeling Liquid-to-Skin Transfer for Known Virus Concentrations. The data of virus transfer from liquid-to-skin 
Table 2. Summary of the Mean Linear Model Parameters for the $\log _{10}$ Transformed Data-Slope ( $m$ ) and Intercept $(b)$ - with 95\% CI, Number of Replicates $(N)$ and the Goodness-of-Fit $\left(R^{2}\right)$ for the Unadsorbed and Adsorbed Fraction of the Three Different Bacteriophages ${ }^{a}$

\begin{tabular}{|c|c|c|c|c|c|c|c|c|}
\hline & \multicolumn{4}{|c|}{ unadsorbed } & \multicolumn{4}{|c|}{ adsorbed } \\
\hline & $m$ & $b$ & & & $m$ & $b$ & & \\
\hline & $(95 \% \mathrm{CI})$ & $(95 \% \mathrm{CI})$ & $N$ & $R^{2}$ & $(95 \% \mathrm{CI})$ & $(95 \% \mathrm{CI})$ & $N$ & $R^{2}$ \\
\hline $\mathrm{MS}^{\mathrm{A}}$ & $1.05(1.11,0.99)$ & $-2.33(-1.88,-2.79)$ & 70 & 0.93 & $1.10(1.02,1.17)$ & $-3.86(-4.38,-3.33)$ & 70 & 0.93 \\
\hline $\mathrm{Q} \beta^{\mathrm{AB}}$ & $0.90(0.98,0.86)$ & $-1.55(-1.13,-1.97)$ & 71 & 0.91 & $1.01(0.93,1.10)$ & $-3.06(-3.68,-2.46)$ & 71 & 0.89 \\
\hline$\Phi 6^{\mathrm{B}}$ & $0.94(1.01,0.83)$ & $-1.40(-0.72,-2.07)$ & 67 & 0.86 & $0.91(0.74,1.07)$ & $-2.62(-3.86,-1.38)$ & 67 & 0.63 \\
\hline All & $0.98(1.02,0.93)$ & $-1.83(-1.52,-2.14)$ & 210 & 0.89 & $0.98(0.91,1.05)$ & $-3.01(-3.51,-2.51)$ & 210 & 0.79 \\
\hline
\end{tabular}

Table 3. Summary of Skin-to-Liquid Theoretical Transfer Efficiency, Recoverable Transfer Efficiency and Total Recovery As a Function of Drying Condition and Liquid ${ }^{a}$

\begin{tabular}{|c|c|c|c|c|c|c|}
\hline & \multicolumn{2}{|c|}{ theoretical $\mathrm{TE}_{\mathrm{S}-\mathrm{L}}{ }^{b}$ mean $\pm \mathrm{SD}[\%]$} & \multicolumn{2}{|c|}{ recoverable $\mathrm{TE}_{\mathrm{S}-\mathrm{L}}{ }^{c}$ mean $\pm \mathrm{SD}[\%]$} & \multicolumn{2}{|c|}{ total recovery $^{d}$ mean $\pm \mathrm{SD}[\%]$} \\
\hline & wet transfer & dry transfer & wet transfer & dry transfer & wet transfer & dry transfer \\
\hline skin-to-saliva & $58.3 \pm 14.8$ & $20.1 \pm 6.3$ & $87.5 \pm 6.3$ & $44.4 \pm 13.1$ & $66.3 \pm 15.6$ & $49.5 \pm 21.0$ \\
\hline skin-to-water & $89.7 \pm 18.9$ & $30.2 \pm 16.7$ & $95.0 \pm 11.7$ & $48.0 \pm 14.3$ & $94.1 \pm 18.6$ & $60.5 \pm 21.6$ \\
\hline
\end{tabular}

${ }^{a_{T}}$ The mean and standard deviation for 14 replicates are reported. ${ }^{b}$ Theoretical transfer efficiency= virus recovered in the liquid/(volume of the inoculum $\times$ concentration of virus in the inoculum $) \times 100 .{ }^{c}$ Recoverable transfer efficiency $=$ virus recovered in the liquid/(virus recovered in the liquid + virus recovered on the skin $) \times 100 .{ }^{d}$ Total recovery= virus recovered in the liquid + virus recovered on the skin $\times 100$.

were adequately described by a linear regression model, as shown with $\mathrm{R}^{2}$ values ranging from 0.63 to 0.93 for adsorbed or unadsorbed viruses (eq 6 and 7, Table 2). Specifically:

$$
n=10^{b} C^{m}
$$

Which can be log-transformed:

$$
\log _{10} n=m \log _{10} C+b
$$

where $n$ is the number of viruses transferred per unit surface area [viruses $/ \mathrm{cm}^{2}$ ], $C$ is the concentration of viruses in the liquid [viruses $/ \mathrm{cm}^{3}$ ], and $m$ and $b$ are the slope and intercept estimated using linear regression of the $\log _{10}$ transformed data. This regression model (eq 6) is equivalent to the Freundlich isotherm, which is a relationship commonly applied to virus adsorption. $^{27,32,33,48-50}$

Note that the constant $m$ is not significantly different than unity in all but one case. Therefore, the eq 6 can be reduced to the linearized form $n=10^{b} C$, which implies a linear relationship between both the adsorbed and the unadsorbed virus transferred, and the concentration of virus in the liquid.

Virus Transfer from Skin-to-Liquid. The theoretical transfer efficiency for skin-to-liquid $\left(\mathrm{TE}_{\mathrm{S}-\mathrm{L}}\right)$ was significantly influenced by the liquid used to recover the virus (saliva or water) (two-way ANOVA, $F(1,52)=26.8), p<0.001, \eta p^{2}=$ $0.34)$. Skin-to-water transfer was, on average, $42 \%$ higher than skin-to-saliva transfer in wet conditions and $40 \%$ higher in dry conditions (Table 3). Allowing the liquid to dry on the skin before performing the transfer experiment significantly decreased the number of viruses transferred $(F(1,52)=$ 149.4, $\left.p<0.001, \eta p^{2}=0.74\right)$.

When the transfer efficiency was calculated using only the recovered virus (Recoverable $T E_{\mathrm{S}-\mathrm{L}}$ ), there was a small but significant effect of the liquid used to recover the virus on the percentage of virus transferred $(F(1,52)=4.7, p=0.03$, $\left.\eta p^{2}=0.08\right)$. In addition, the transfer was significantly lower when the liquid was dried prior the transfer event $(F(1,52)=259.5, p$ $\left.<0.001, \eta p^{2}=0.83\right)$. Similarly, the total recovery was statistically significantly influenced by the liquid used $(F(1,52)=14.12$, $p$ $\left.<0.001, \eta p^{2}=0.21\right)$ and allowing the inoculum to dry significantly decreased the total number of viruses recovered ( $F$ $\left.(1,52)=23.88, p<0.001, \eta p^{2}=0.31\right)$.

\section{DISCUSSION}

Our study shows that transfer of viruses from liquid-to-skin can be described by a single model based only on the concentration of virus in the liquid. Therefore, this model applies to a wide range of water-related activities, including those that are short and long duration, with different liquids (for example, seawater, freshwater, urine), and with different viruses, including both enveloped and nonenveloped viruses. As shown in the present study, contact times considered ( $5 \mathrm{~s}$ to $30 \mathrm{~min}$ ) had little-to-no influence on virus transfer, suggesting an apparent equilibrium between viruses adsorbed on the surface and virus in the liquid was reached within five seconds. Similarly, there was no statistically significant difference observed between the liquid conditions ( $\mathrm{pH} 6-9$, IS 10-550 $\mathrm{mM}$ ) and the differences observed between viruses (MS2, $\mathrm{Q} \beta$, and $\Phi 6$ ) tested were not biologically meaningful as defined here by having an effect size of less than $2 \%$. This differs from previous studies showing virus species and liquid conditions influence virus adsorption to surfaces in a variety of batch and flow-through column experiments $^{26,27,51}$ as well as Quartz Crystal Microbalance with Dissipation (QCM-D) experiments. ${ }^{29,30}$

The apparent discrepancy between our cohort studies and previous liquid-to-surfaces studies is likely attributed to differences in experimental methods and natural heterogeneity of skin surfaces. The three cohort studies were performed at virus concentrations between $10^{6}$ and $10^{8} \mathrm{PFU} / \mathrm{ml}$. Higher concentrations were considered not relevant for most exposure assessments, while lower concentrations resulted in transfer quantities close to our limit of detection $\left(100 \mathrm{PFU} / \mathrm{cm}^{2}\right)$. Additionally, we asked the volunteers not to wash their hands prior the experiment, potentially leading to a high betweensubjects variation, as compared with within-subjects variation. This could have obscured the contribution of other factors (virus species, contact time, liquid characteristics) to virus 
transfer. We did not collect data on skin characteristics (e.g., $\mathrm{pH}$, water content) or personal hygiene information (e.g., time since last hand washing). The study was insufficiently powered to assess these factors, though they may have influenced transfer.

The transfer model from liquid-to-skin highlights the importance of the volume of liquid remaining on the skin after contact and the concentration of viruses in the liquid. Water volume influences the number of "unadsorbed" viruses that are transferred to the skin, whereas concentration influences both "unadsorbed" and "adsorbed" fraction of viruses. This result is consistent with studies of virus transfer between skin and fomites ${ }^{19}$ where the concentration of viruses on the fomites was proportional to the number of viruses transferred to the skin. In the present study, the "unadsorbed" fraction was the main driver of virus transfer. After liquid-toskin contact, removing the excess liquid on skin will significantly reduce the indirect (water-mediated) transfer of viruses, but a fraction of the viruses will remain on the skin ("adsorbed") even after complete removal of the liquid.

In addition to our liquid-to-skin model, we developed a model for subsequent skin-to-liquid transfer. The wetness of the skin significantly influences virus transfer. Up to $90 \pm 19 \%$ of the virus inoculated on the skin are ready to be transferred to the water when the inoculum is wet and $30 \pm 17 \%$ when it is dry. The relatively low transfer of viruses in dry conditions could be partially explained by the inactivation of nonenveloped viruses on human hands. Ansari et al. (1988) estimated that only $57 \%$ and $43 \%$ of rotavirus was recoverable 20 and $60 \mathrm{~min}$ after inoculation onto hands, respectively. ${ }^{36}$ Skin-to-saliva transfer was significantly less than skin-to-water, which can be partially explained by saliva's antiviral properties. ${ }^{52-54}$ Our experimental controls showed that MS2 counts were 19\% lower if the MS2 was kept for 2 to $6 \mathrm{~h}$ in PBS + saliva as compared with PBS + water (SI S3.1). Our work on virus transfer from skin-to-saliva provides insight into virus transfer during handto-mouth contacts, which contribute to infection risks ${ }^{15,17,55-57}$ and are relatively frequent, especially among children. ${ }^{58,59}$

The enveloped bacteriophage $\Phi 6$ behaved similarly to the two nonenveloped viruses. Most studies of virus fate in the environment are based on nonenveloped viruses since they are more persistent than enveloped viruses. Nevertheless, it has been shown that enveloped viruses can survive for days to weeks, depending on virus characteristics and environmental conditions. $^{38,39,44,60,61}$ Furthermore, in an aqueous environment, enveloped viruses are readily adsorbed onto the solid phase. $^{39}$ The risk that potentially pandemic enveloped viruses such as ebola, avian influenza, Middle East respiratory syndrome (MERS-CoV) and severe acute respiratory syndrome (SARS) pose for human health ${ }^{62}$ highlights the importance of studying the fate and transfer of enveloped viruses. Our data suggest that when modeling virus transfer between liquid and skin, the same model can be used for enveloped and nonenveloped viruses. Although transfer efficiency may be similar, risks may still differ for enveloped viruses due to differences in transmission route (i.e., bloodborne transmission as opposed to fecal-oral transmission).

Our results suggest that consideration of virus transfer (from liquid-to-skin) due to bulk liquid transfer alone underestimates infection risks. To date, the virus adsorption component has been neglected in risk assessments. As previously discussed, De Man et al. used information on the thickness of the water film that remained on the skin and the pathogen concentration in the water to estimate the total pathogen transfer. ${ }^{15}$ Using their assumptions (average film thickness $=2.16 \times 10^{-3} \mathrm{~cm}$ ), when concentration is $10^{4}$ viruses $/ \mathrm{cm}^{3}$, a total of 21.6 viruses $/ \mathrm{cm}^{2}$ would be transferred to the skin, which represents the "unadsorbed" fraction. Based on our model (eq 5), the number of viruses adsorbed to the skin when virus concentration is $10^{4}$ viruses $/ \mathrm{cm}^{3}$ is equal to $10^{-3.01} \times 10^{4}$, which is 9.8 viruses $/ \mathrm{cm}^{2}$. These results would shift the estimate $37 \%$, from 21.6 to 31.3 $(21.6+9.8)$ viruses $/ \mathrm{cm}^{2}$. De Man et al. assumed that $100 \%$ of the unadsorbed pathogens are transferred to the mouth after contact $\left(21.6\right.$ pathogens $\left./ \mathrm{cm}^{2}\right)$. Our results suggest that, in the case of viruses, only $58.3 \%$ are transferred after hand-to-mouth contact, when the hand is still wet, leading to a final transfer of 18.3 viruses $/ \mathrm{cm}^{2}$ (31.3 viruses $\left./ \mathrm{cm}^{2} \times 0.58\right)$.

Indirect transmission of pathogens is especially important in scenarios involving children playing in areas exposed to liquids contaminated with viruses such as slum flooded zones ${ }^{63}$ and open drains, ${ }^{64}$ as hand-to-mouth contact frequency in children is high. ${ }^{58}$ Future QMRA studies should incorporate indirect transmission of pathogens through water to evaluate its relative contribution to overall risk. Transfer from liquid to skin should be modeled to quantify the number of viruses that remain transferable during subsequent hand-mouth contacts, which includes the number of viruses adsorbed on the skin and the number of viruses retained in the liquid on the skin. The volume of liquid remaining on skin depends on the activity performed. ${ }^{58}$ In this work we suggest an equation to estimate the unadsorbed fraction of viruses as a function of concentration, which could be used in QMRA studies if no prior information regarding the amount of liquid transferred is known. Nevertheless, the volume of liquid retained on the skin in the experiments performed could have been influenced by the experimental method, therefore, a more comprehensive study of liquid transfer to skin after different activities is needed to have a more accurate estimate of the number of unadsorbed viruses on the skin.

\section{ASSOCIATED CONTENT}

\section{S Supporting Information}

The Supporting Information is available free of charge on the ACS Publications website at DOI: 10.1021/acs.est.7b04949.

A figure of the method used to estimate virus transfer from (1) liquid-to-skin and (2) from skin-to-liquid; a description of the adsorption of bacteriophage to Vaseline compared to human skin; a description of the influence of the droplet environment on bacteriophage MS2 survival; a figure of bacteriophages (MS2, $\mathrm{Q} \beta$, and Ф6) transferred to the skin as a function of contact time for three different concentrations; a figure of bacteriophage $\mathrm{Q} \beta$ transferred to the skin as a function of concentration and contact time; a figure of the adsorption of bacteriophage MS2 to the skin as a function of liquid characteristics; a description of bacteriophage MS2 survival in saliva and water (PDF)

\section{AUTHOR INFORMATION}

\section{Corresponding Author}

*Phone: +41 58765 5632; e-mail: tim.julian@eawag.ch.

ORCID

Tamar Kohn: 0000-0003-0395-6561

Timothy R. Julian: 0000-0003-1000-0306 


\section{Notes}

The authors declare no competing financial interest.

\section{ACKNOWLEDGMENTS}

This research was funded by Eawag Discretionary Funds for Research. We thank the volunteers for their participation.

\section{REFERENCES}

(1) Kotloff, K. L.; Nataro, J. P.; Blackwelder, W. C.; Nasrin, D.; Farag, T. H.; Panchalingam, S.; Wu, Y.; Sow, S. O.; Sur, D.; Breiman, R. F.; et al. Burden and aetiology of diarrhoeal disease in infants and young children in developing countries (the Global Enteric Multicenter Study, GEMS): a prospective, case-control study. Lancet 2013, 382 (9888), 209-222.

(2) Walker, C. L. F.; Rudan, I.; Liu, L.; Nair, H.; Theodoratou, E.; Bhutta, Z. A.; O’Brien, K. L.; Campbell, H.; Black, R. E. Global burden of childhood pneumonia and diarrhoea. Lancet 2013, 381 (9875), $1405-1416$.

(3) La Rosa, G.; Fratini, M.; Della Libera, S.; Iaconelli, M.; Muscillo, $\mathrm{M}$. Emerging and potentially emerging viruses in water environments. Ann. Ist. Super. Sanita 2012, 162 (1), 51-59.

(4) Sinclair, R. G.; Jones, E. L.; Gerba, C. P. Viruses in recreational water-borne disease outbreaks: A review. J. Appl. Microbiol. 2009, 107 (6), 1769-1780.

(5) Bosch, A. Human enteric viruses in the water environment: A minireview. Int. Microbiol. 1998, 1 (3), 191-196.

(6) Kawata, K. Water and other environmental interventions-The minimum investment concept. Am. J. Clin. Nutr. 1978, 31, 2114-2123.

(7) Vergara, G. G. R. V.; Rose, J. B.; Gin, K. Y. H. Risk assessment of noroviruses and human adenoviruses in recreational surface waters. Water Res. 2016, 103, 276-282.

(8) Soller, J. a.; Eftim, S.; Wade, T. J.; Ichida, A. M.; Clancy, J. L.; Johnson, T. B.; Schwab, K.; Ramirez-Toro, G.; Nappier, S.; Ravenscroft, J. E. Use of quantitative microbial risk assessment to improve interpretation of a recreational water epidemiological study. Microbial Risk Analysis 2015, 000, 1-10.

(9) Schets, F. M.; Schijven, J. F.; de Roda Husman, A. M. Exposure assessment for swimmers in bathing waters and swimming pools. Water Res. 2011, 45 (7), 2392-2400.

(10) Boehm, A. B.; Ashbolt, N. J.; Colford, J. M.; Dunbar, L. E.; Fleming, L. E.; Gold, M. A.; Hansel, J. A.; Hunter, P. R.; Ichida, A. M.; McGee, C. D.; et al. A sea change ahead for recreational water quality criteria. J. Water Health 2009, 7 (1), 9-20.

(11) Diallo, M. B. C.; Anceno, A. J.; Tawatsupa, B.; Houpt, E. R.; Wangsuphachart, V.; Shipin, O. V. Infection risk assessment of diarrhea-related pathogens in a tropical canal network. Sci. Total Environ. 2008, 407 (1), 223-232.

(12) Machdar, E.; van der Steen, N. P.; Raschid-Sally, L.; Lens, P. N. L. Application of Quantitative Microbial Risk Assessment to analyze the public health risk from poor drinking water quality in a low income area in Accra, Ghana. Sci. Total Environ. 2013, 449, 134-142.

(13) Soller, J. A.; Bartrand, T.; Ashbolt, N. J.; Ravenscroft, J.; Wade, T. J. Estimating the primary etiologic agents in recreational freshwaters impacted by human sources of faecal contamination. Water Res. 2010, 44 (16), 4736-4747.

(14) Dorevitch, S.; Panthi, S.; Huang, Y.; Li, H.; Michalek, A. M.; Pratap, P.; Wroblewski, M.; Liu, L.; Scheff, P. a.; Li, A. Water ingestion during water recreation. Water Res. 2011, 45 (5), 2020-2028.

(15) De Man, H.; Bouwknegt, M.; van Heijnsbergen, E.; Leenen, E. J. T. M.; van Knapen, F.; de Roda Husman, A. M. Health risk assessment for splash parks that use rainwater as source water. Water Res. 2014, 54, 254-261.

(16) O’Toole, J.; Sinclair, M.; Malawaraarachchi, M.; Hamilton, A.; Barker, S. F.; Leder, K. Microbial quality assessment of household greywater. Water Res. 2012, 46 (13), 4301-4313.

(17) De Man, H.; van den Berg, H. H. J. L.; Leenen, E. J. T. M.; Schijven, J. F.; Schets, F. M.; van der Vliet, J. C.; van Knapen, F.; de Roda Husman, A. M. Quantitative assessment of infection risk from exposure to waterborne pathogens in urban floodwater. Water Res. 2014, 48, 90-99.

(18) Ansari, S.; Springthorpe, V.; Sattar, S.; Rivard, S.; Rahman, M. Potential role of hands in the spread of respiratory viral infections: studies with human parainfluenza virus 3 and rhinovirus. J. Clin. Microbiol. 1991, 29 (10), 2115-2119.

(19) Julian, T. R.; Leckie, J. O.; Boehm, A. B. Virus transfer between fingerpads and fomites. J. Appl. Microbiol. 2010, 109, 1868-1874.

(20) Rusin, P.; Maxwell, S.; Gerba, C. Comparative surface-to-hand and fingertip-to-mouth transfer efficiency of gram-positive bacteria, gram-negative bacteria, and phage. J. Appl. Microbiol. 2002, 93, 585592.

(21) Lopez, G. U.; Gerba, C. P.; Tamimi, A. H.; Kitajima, M.; Maxwell, S. L.; Rose, J. B. Transfer efficiency of bacteria and viruses from porous and nonporous fomites to fingers under different relative humidity conditions. Appl. Environ. Microbiol. 2013, 79, 5728-5734.

(22) Bidawid, S.; Malik, N.; Adegbunrin, O.; Sattar, S. A.; Farber, J. M. Norovirus cross-contamination during food handling and interruption of virus transfer by hand antisepsis: experiments with feline calicivirus as a surrogate. J. Food Prot. 2004, 67 (1), 103-109.

(23) Verhaelen, K.; Bouwknegt, M.; Carratalà, A.; Lodder-Verschoor, F.; Diez-Valcarce, M.; Rodríguez-Lázaro, D.; de Roda Husman, A. M.; Rutjes, S. a. Virus transfer proportions between gloved fingertips, soft berries, and lettuce, and associated health risks. Int. J. Food Microbiol. 2013, 166 (3), 419-425.

(24) Vega, E.; Smith, J.; Garland, J.; Matos, A.; Pillaii, S. D. Variability of virus attachment patterns to butterhead lettuce. J. Food Prot. 2005, 68 (10), 2112-2117.

(25) Vega, E.; Garland, J.; Pillai, S. D. Electrostatic forces control nonspecific virus attachment to lettuce. J. Food Prot. 2008, 71 (3), $522-529$.

(26) Taylor, D. H.; Moore, R. S.; Sturman, L. S. Influence of pH and electrolyte composition on adsorption of poliovirus by soils and minerals. Appl. Environ. Microbiol. 1981, 42 (6), 976-984.

(27) Schijven, J. F.; Majid Hassanizadeh, S.; Dowd, S. E.; Pillai, S. D. Modeling Virus Adsorption in Batch and Column Experiments. Quant. Microbiol. 2000, 2 (1), 5-20.

(28) Redman, J. a.; Grant, S. B.; Olson, T. M.; Hardy, M. E.; Estes, M. K. Filtration of recombinant norwalk virus particles and bacteriophage MS2 in quartz sand: Importance of electrostatic interactions. Environ. Sci. Technol. 1997, 31 (12), 3378-3383.

(29) Yuan, B.; Pham, M.; Nguyen, T. H. Deposition kinetics of bacteriophage MS2 on a silica surface coated with natural organic matter in a radial stagnation point flow cell. Environ. Sci. Technol. 2008, 42 (20), 7628-7633.

(30) Armanious, A.; Aeppli, M.; Jacak, R.; Refardt, D.; Sigstam, T.; Kohn, T.; Sander, M. Viruses at solid-water interfaces: A systematic assessment of interactions driving adsorption. Environ. Sci. Technol. 2016, 50 (2), 732-743.

(31) Armanious, A.; Munch, M.; Kohn, T.; Sander, M. Competitive co-adsorption dynamics of viruses and dissolved organic matter to positively charged sorbent surfaces. Environ. Sci. Technol. 2016, 50 (7), 3597-3606.

(32) Gerba, C. Applied and Theoretical Aspects of Virus Adsorption to Surfaces. Adv. Appl. Microbiol. 1984, 30, 133-168.

(33) Jin, Y.; Flury, M. Fate and Transport of Viruses in Porous Media. Adv. Agron. 2002, 77, 39-102.

(34) Michen, B.; Graule, T. Isoelectric points of viruses. J. Appl. Microbiol. 2010, 109 (2), 388-397.

(35) Lukasik, J.; Scott, T. M.; Andryshak, D.; Farrah, S. R. Influence of salts on virus adsorption to microporous filters. Appl. Environ. Microbiol. 2000, 66 (7), 2914-2920.

(36) Ansari, S. a.; Sattar, S. a.; Springthorpe, V. S.; Wells, G. a.; Tostowaryk, W. Rotavirus survival on human hands and transfer of infectious virus to animate and nonporous inanimate surfaces. J. Clin. Microbiol. 1988, 26, 1513-1518.

(37) Mbithi, J. N.; Springthorpe, V. S.; Boulet, J. R.; Sattar, S. A. Survival of hepatitis A virus on human hands and its transfer on 
contact with animate and inanimate surfaces. J. Clin. Microbiol. 1992, 30 (4), 757-763.

(38) Casanova, L.; Rutala, W. A.; Weber, D. J.; Sobsey, M. D. Survival of surrogate coronaviruses in water. Water Res. 2009, 43 (7), 18931898.

(39) Ye, Y.; Ellenberg, R. M.; Graham, K. E.; Wigginton, K. R. Survivability, Partitioning, and Recovery of Enveloped Viruses in Untreated Municipal Wastewater. Environ. Sci. Technol. 2016, 50 (10), 5077-5085.

(40) O’Toole, J.; Sinclair, M.; Leder, K. Transfer rates of enteric microorganisms in recycled water during machine clothes washing. Appl. Environ. Microbiol. 2009, 75 (5), 1256-1263.

(41) Grabow, W. Bacteriophages: update on application as models for viruses in water. Water SA 2001, 27 (2), 251-268.

(42) Gallandat, K.; Wolfe, M. K.; Lantagne, D. Surface Cleaning and Disinfection: Efficacy Assessment of Four Chlorine Types Using Escherichia coli and the Ebola Surrogate \$6. Environ. Sci. Technol. 2017, 51 (8), 4624-4631.

(43) Turgeon, N.; Toulouse, M.-J.; Martel, B.; Moineau, S.; Duchaine, C. Comparison of five bacteriophages as models for viral aerosol studies. Appl. Environ. Microbiol. 2014, 80 (14), 4242-4250.

(44) Casanova, L. M.; Weaver, S. R. Inactivation of an Enveloped Surrogate Virus in Human Sewage. Environ. Sci. Technol. Lett. 2015, 2 (3), 76-78.

(45) Casanova, L. M.; Weaver, S. R. Evaluation of eluents for the recovery of an enveloped virus from hands by whole-hand sampling. $J$. Appl. Microbiol. 2015, 118 (5), 1210-1216.

(46) USEPA. EPA Method 1602. Male-Specific $(F+)$ and Somatic Coliphage in Water by Single Agar Layer (SAL) Procedure, Technical Report EPA 821-R-01-029; U.S. Environmental Protection Agency.

(47) Zhuang, J.; Jin, Y. Virus retention and transport through Aloxide coated sand columns: effects of ionic strength and composition. J. Contam. Hydrol. 2003, 60 (3-4), 193-209.

(48) Chrysikopoulos, C. V.; Aravantinou, A. F. Virus attachment onto quartz sand: Role of grain size and temperature. J. Environ. Chem. Eng. 2014, 2 (2), 796-801.

(49) Chrysikopoulos, C. V.; Syngouna, V. I. Attachment of bacteriophages MS2 and $\Phi$ X174 onto kaolinite and montmorillonite: extended-DLVO interactions. Colloids Surf., B 2012, 92, 74-83.

(50) Mi, X.; Heldt, C. L. Adsorption of a non-enveloped mammalian virus to functionalized nanofibers. Colloids Surf., B 2014, 121, 319324.

(51) Jin, Y.; Yates, M. V.; Thompson, S. S.; Jury, W. A. Sorption of Viruses during Flow through Saturated Sand Columns. Environ. Sci. Technol. 1997, 31 (2), 548-555.

(52) Pirtle, E. C.; Beran, G. W. Virus survival in the environment. Rev. Sci. Tech 1991, 10 (3), 733-748.

(53) Zuo, Z.; Kuehn, T. H.; Bekele, A. Z.; Mor, S. K.; Verma, H.; Goyal, S. M.; Raynor, P. C.; Pui, D. Y. H. Survival of airborne MS2 bacteriophage generated from human saliva, artificial saliva, and cell culture medium. Appl. Environ. Microbiol. 2014, 80 (9), 2796-2803.

(54) Malamud, D.; Abrams, W. R.; Barber, C. A.; Weissman, D.; Rehtanz, M.; Golub, E. Antiviral activities in human saliva. Adv. Dent. Res. 2011, 23 (1), 34-37.

(55) Tamimi, A. H.; Maxwell, S.; Edmonds, S. L.; Gerba, C. P. Impact of the use of an alcohol-based hand sanitizer in the home on reduction in probability of infection by respiratory and enteric viruses. Epidemiol. Infect. 2015, 143 (15), 3335-3341.

(56) Julian, T. R.; Canales, R. a.; Leckie, J. O.; Boehm, A. B. A model of exposure to rotavirus from nondietary ingestion iterated by simulated intermittent contacts. Risk Anal 2009, 29, 617-632.

(57) Mattioli, M. C. M.; Davis, J.; Boehm, A. B. Hand-to-mouth contacts result in greater ingestion of feces than dietary water consumption in Tanzania: A quantitative fecal exposure assessment model. Environ. Sci. Technol. 2015, 49, 1912-1920.

(58) U.S. Environmental Protection Agency. Exposure Factors Handbook, 2011 ed.; EPA/600/R; U.S. Environmental Protection Agency, 2011; (September), pp 1-1466.
(59) Kwong, L. H.; Ercumen, A.; Pickering, A. J.; Unicomb, L.; Davis, J.; Luby, S. P. Hand- and Object-Mouthing of Rural Bangladeshi Children 3-18 Months Old. Int. J. Environ. Res. Public Health 2016, 13 (6), 563.

(60) Aquino de Carvalho, N.; Stachler, E. N.; Cimabue, N.; Bibby, K. Evaluation of $\Phi 6$ Persistence and Suitability as an Enveloped Virus Surrogate. Environ. Sci. Technol. 2017, 51 (15), 8692-8700.

(61) Sobsey, M. D.; Meschke, J. S. Virus survival in the environment with special attention to survival in sewage droplets and other environmental media of fecal or respiratory origin. In Report for the World Health Organization; Geneva, Switzerland, 2003; p 70.

(62) Weber, D. J.; Rutala, W. A.; Fischer, W. A.; Kanamori, H.; Sickbert-Bennett, E. E. Emerging infectious diseases: Focus on infection control issues for novel coronaviruses (Severe Acute Respiratory Syndrome-CoV and Middle East Respiratory Syndrome$\mathrm{CoV})$, hemorrhagic fever viruses (Lassa and Ebola), and highly pathogenic avian influenza viruses, $\mathrm{A}(\mathrm{H} 5 \mathrm{~N} 1)$ and $\mathrm{A}(\mathrm{H} 7 \mathrm{~N} 9)$. Am. J. Infect. Control 2016, 44 (5 Suppl), e91-e100.

(63) Fuhrimann, S.; Winkler, M. S.; Stalder, M.; Niwagaba, C. B.; Babu, M.; Kabatereine, N. B.; Halage, A. A.; Utzinger, J.; Cissé, G.; Nauta, M. Disease burden due to gastrointestinal pathogens in a wastewater system in Kampala, Uganda. Microbial Risk Analysis 2016, 4 (Supplement C), 16-28.

(64) Wang, Y.; Moe, C. L.; Null, C.; Raj, S. J.; Baker, K. K.; Robb, K. A.; Yakubu, H.; Ampofo, J. A.; Wellington, N.; Freeman, M. C.; et al. Multipathway Quantitative Assessment of Exposure to Fecal Contamination for Young Children in Low-Income Urban Environments in Accra, Ghana: The SaniPath Analytical Approach. Am. J. Trop. Med. Hyg. 2017, 97 (4), 1009-1019. 